\title{
PHYLOGENETIC RELATIONSHIPS AND DISTRIBUTION OF THE RHIZOTROGINI (COLEOPTERA, SCARABAEIDAE, MELOLONTHINAE) IN THE WEST MEDITERRANEAN
}

\author{
M . M. Coca-Abia*
}

\begin{abstract}
In this paper, the West Mediterranean genera of Rhizotrogini are reviewed. Two kinds of character sets are discussed: those relative to the external morphology of the adult and those of the male and female genitalia. Genera Amadotrogus Reitter, 1902; Amphimallina Reitter, 1905; Amphimallon Berthold, 1827; Geotrogus Guérin-Méneville, 1842; Monotropus Erichson, 1847; Pseudoapeterogyna Escalera, 1914 and Rhizotrogus Berthold, 1827 are analysed: to demonstrate the monophyly of this group of genera; to asses the realtionships of these taxa; to test species transferred from Rhizotrogus to Geotrogus and Monotropus, and to describe external morphological and male and female genitalic characters which distinguish each genus. Phylogenetic analysis leads to the conclusion that this group of genera is monophyletic. However, nothing can be said about internal relationships of the genera, which remain in a basal polytomy. Some of the species tranferred from Rhizotrogus are considered to be a new genus Firminus. The genera Amphimallina and Pseudoapterogyna are synonymized with Amphimallon and Geotrogus respectively.
\end{abstract}

Key words: Taxonomy, nomenclature, review, Coleoptera, Scarabaeidae, Melolonthinae, Rhizotrogini, Amadotrogus, Amphimallon, Rhizotrogus, Geotrogus, Pseudoapterogyna, Firminus, Mediterranean basin.

\section{RESUMEN}

Relaciones filogenéticas y distribución de los Rhizotrogini (Coleoptera, Scarabaeidae, Melolonthinae) en el Mediterráneo occidental

En este trabajo se revisan los géneros de Rhizotrogini del Mediterraneo Occidental. Dos clases de caracteres son estudiados; los correspondientes a la morfología externa de los adultos y a las genitalias femenina y masculina. Se estudian los géneros Amadotrogus Reitter, 1902; Amphimallina Reitter, 1905; Amphimallon Berthold, 1827; Geotrogus Guérin-Méneville, 1842; Monotropus Erichson, 1847; Pseudoapeterogyna Escalera, 1914 y Rhizotrogus Berthold, 1827, para comprobar la monofilia del grupo; evaluar sus relaciones filogenéticas; comprobar que la transferencia de especies de Rhizotrogus a Geotrogus y Monotropus estuvo bien establecida y describir la morfología externa y genitalia femenina y masculina de los géneros implicados. El análisis filogenético permite concluir que estos géneros constituyen un grupo monofilético. Sin embargo, poco se puede decir sobre las relaciones filogenéticas internas de este clado, las cuales permanecen en una politomia basal. Algunas de las especies tranferidas de Rhizotrogus son consideradas un nuevo género Firminus. Los generos Amphimallina y Pseudoapterogyna son sinonimizados con Amphimallon y Geotrogus respectivamente.

Palabras clave: Taxonomía, nomenclatura, revisión, Coleoptera, Scarabaeidae, Melolonthinae, Rhizotrogini, Amadotrogus, Amphimallon, Rhizotrogus, Geotrogus, Pseudoapterogyna, Firminus, Mediterráneo Occidental.

* Museo Nacional de Ciencias Naturales (CSIC). Dpto. Biodiversidad y Biología Evolutiva (Entomología). José Gutiérrez Abascal, 2. 28006 Madrid (Spain). mcnc171@mncn.csic.es 


\section{Introduction}

The Melolonthinae constitutes one of the most morphologically diversified subfamilies of all Scarab beetles. This Subfamily is comprised of many tribes, two of them Melolonthini and Rhizotrogini, with such geographically widespread genera as Melolontha F., 1775; Anoxia Castelnau, 1832; Polyphylla Harris, 1841; Rhizotrogus Berthold, 1827; Amphimallon Berthold, 1827; Amphimallina Reitter, 1905 Monotropus Erichson, 1848; Amadotrogus Reitter, 1902; Geotrogus Guérin-Méneville, 1842; Pseudoapterogyna Escalera, 1914; Miltotrogus Reitter, 1890, Haplidia Hope, 1837, among others.

In most cases, interest in Melolonthinae has been focused on the anatomy of the copulatory organs (Krell, 1996a; Coca-Abia \& Martín-Piera, 1991), anatomy of genital muscles (Krell, 1996b), pest control of white grubs (Alvarado et al., 1996), and descriptions for taxonomic revisions (Paulian \& Baraud, 1982; Baraud, 1992; Coca-Abia \& Martín-Piera, 1998). However, because of its considerable taxonomic diversity, the phylogenetic analyses have always studied only one part of the group of genera such as Rhizotrogus (Coca-Abia, 1995; Coca-Abia \& Martín-Piera, 1998), Amphimallon (Montreuil, 2000) and Amadotrogus (Coca-Abia \& Martín-Piera, 2002), and in only a few cases, was the phylogenetic analysis broached.

In a worldwide taxonomic revision of the genus Rhizotrogus (Coca-Abia, 1995; Coca-Abia \& Martín-Piera, 1998), some species belonging to this genus were transferred to other West-Palaearctic Melolonthini genera such as Amadotrogus, Monotropus and Geotrogus. The mistake in taxonomic classification was thus demonstrated, and a new taxonomic classification supported by phylogenetic analysis was considered but was never carried out.

In this work, a taxonomic and phylogenetic study of the genera Amadotrogus, Amphimallina, Amphimallon, Geotrogus, Monotropus, Pseudoapterogyna and Rhizotrogus, some of them involved in the transference from Rhizotrogus (Coca-Abia \& Martín Piera, 1998), is carried out in an attempt to provide a better understanding of the West Mediterranean Rhizotrogini fauna.

This paper is an attempt to: 1) demonstrate that the genera Amadotrogus, Amphimallina, Amphimallon, Geotrogus, Monotropus, Pseudoapterogyna, and Rhizotrogus, constitute a monophyletic group strongly supported by synapomorphies, 2) establish the internal phylogenetic relationships between these genera, 3) test species transference from Rhizotrogus to other genera (Geotrogus, Monotropus, and Amadotrogus) (Coca-Abia \& Martín Piera, 1998) and 4) describe external morphological and male and female genitalic characters that distinguish each genus.

\section{Material and methods}

The specimens studied are in collections belonging to the following: Museo Nacional de Ciencias Naturales of Madrid, Museum d'Histoire Naturelle of Paris (MNHN), Martin-Luther-Universitat HalleWittenberg (Saale), Fundación Entomológica "Torres Sala" of Valencia, Museo Civico "Giacomo Doria” of Genova, Museum für Naturkunde (Berlin); Antonio Andújar; Jacques Baraud in MNHN, José Luis Lencina, and José Miguel Avila.

The taxonomic discussion is based on external morphology and male genitalia. The morphology of female genitalia varies little from one to another in the studied taxa and gives few diagnostic characters of low taxonomic rank (Coca-Abia \& Martín-Piera, 1991; Martín-Piera \& Coca-Abia, 1992).

The procedure for preparation of male genitalia was as follows; first, the clearing of the tegmen and endophallus with hot water and potasium hydroxide $(\mathrm{KOH} \mathrm{5 \% ).} \mathrm{Once} \mathrm{cleaned,} \mathrm{a} \mathrm{sagittal} \mathrm{cut} \mathrm{is} \mathrm{made}$ in the endophallus face opposite the tigilla. Then, the endophallus was dehydrated in steps using mixtures of increasing percentages of ethyl alcohol and, finally, pure xylol. The endophallus was finally mounted in Canadian Balsam on a microscope slide.

The preparation of female genitalia for study was the same as that for male genitalia, but the dehydration was less. The female genitalia were mounted in Euparal on a microscope slide.

The phylogenetic analysis was carried out using PAUP 3.1.1 (Swofford, 1993) and MacClade 3.01 (Madison and Madison, 1992). The exhaustive search was used to find the most parsimonious trees. The robustness of the clades was assessed with bootstrapping (Felsenstein, 1985).

All taxa which were thought to belong to the clade constituted by Amadotrogus, Amphimallina, Amphimallon, Geotrogus, Monotropus, Pseudoapterogyna and Rhizotrogus (Coca-Abia, 1995) were included in the analysis. Geotrogus and Pseudoapterogyna were represented by their type species and the species transferred from Rhizotrogus to Geotrogus (Coca-Abia \& MartínPiera, 1998), except for Geotrogus baudii 
Table 1.- Character matrix used in the phylogenetic analysis (Characters are described in the text). Explanation of symbols: $0-3=$ character states, $-=$ state unknown.

Tabla 1. - matriz de caracteres usada en el análisis filogenético (los caracteres se describen en el texto). Simbología: 0-3= estados de los caracteres, - = estado desconocido.

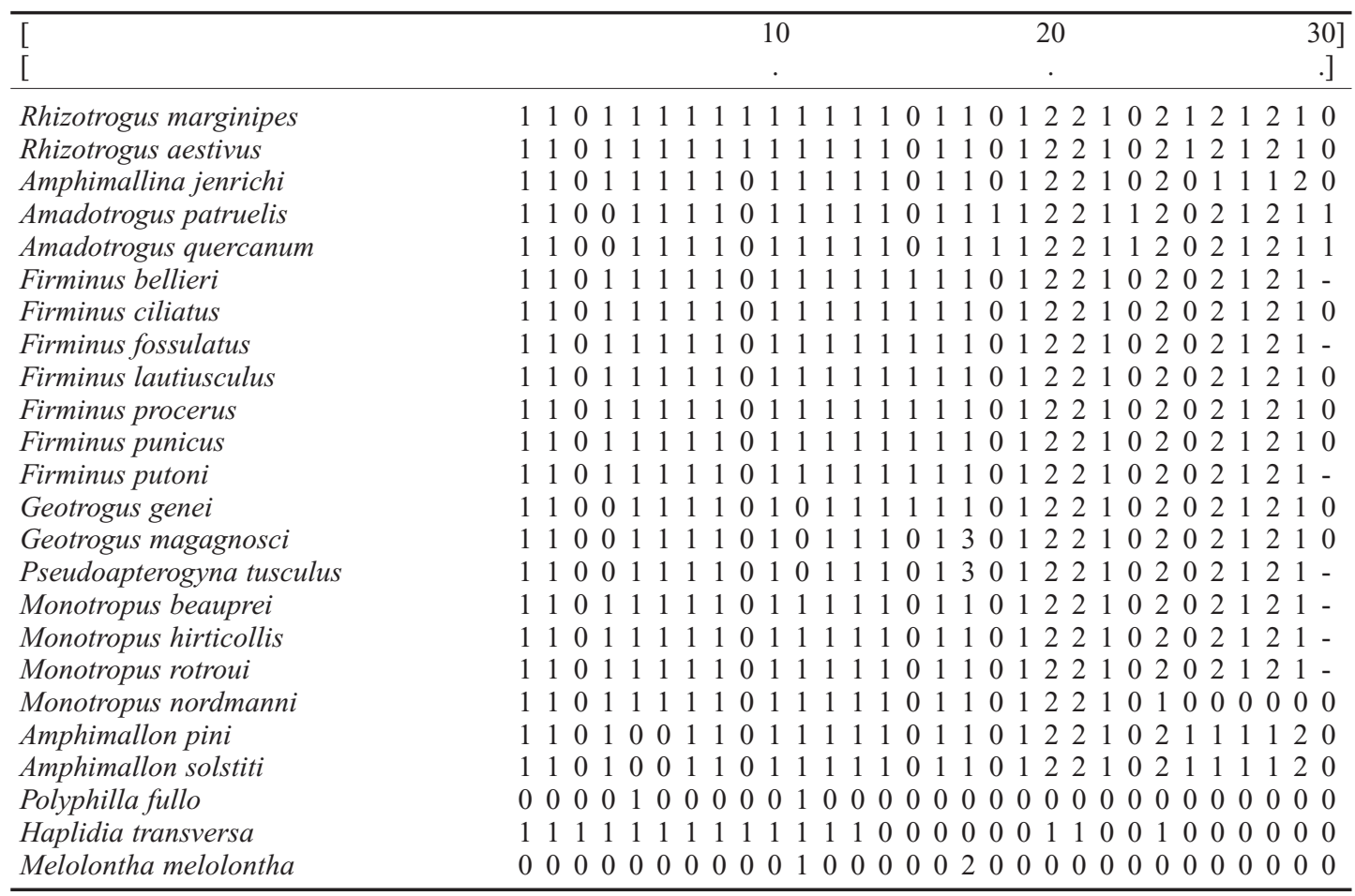

(Brenske, 1886) which was not included in the analysis because male specimens were not studied. For Amphimallon, two more representative species, one of them the type species, were selected, which express the taxon's variability (Mountreuil, 2000). The two species groups of Rhizotrogus (Coca-Abia, 1995; Coca-Abia and Martín-Piera, 1998) were represented by a single species each. Two species of Amadotrogus were included to show the morphological and genitalic variation of that genus (Coca-Abia \& MartínPiera, 2002). Although, in this paper, the rank of interest is the supraspecific, the use of species, rather than a made-up hypothetical groundplan, allows for verification of homology hypotheses and for the testing of the monophyly of the groups. Whenever possible, the type species of the genera were included in the analysis. Although type species of Monotropus (Monotropus nordmanni Blanchard, 1850) was studied and included in the analysis, the type specimens could not be obtai- ned. Also the species transferred from Rhizotrogus to Montropus (Coca-Abia \& Martín Piera, 1998) were included in the analysis.

Polyphylla fullo (L., 1758), Melolontha melolont$h a(\mathrm{~L} ., 1758)$ and Haplidia transversa (F., 1801) were considered outgroups. The two former were chosen because they belong to the Melolonthini tribe, the sister group of the tribe Rhizotrogini in which the ingroup (Amadotrogus, Amphimallina, Amphimallon, Geotrogus, Monotropus, Pseudoapterogyna and Rhizotrogus) is included. However, as Haplidia transversa belongs to Rhizotrogini, the same as the ingroup (Coca-Abia, 1995), it was thus possible to test the monophyly of this group of genera.

The data set comprises 30 characters scored accross 24 taxa. Character selection included twelve from external morphology; seventeen from male genitalia and one from female genitalia. Characters were polarised using the outgroup criterion described by Nixon \& Carpenter (1993). All characters were treated as non-additive (Fitch, 1971). In unor- 
dered multistate characters, the distance between all pairs of states was treated as a single step.

The data matrix (Table 1) represents the character systems and their comparison.

Character 1.- Clypeus sides. (0) parallel or diverging anteriorly; (1) oblique.

Character 2.- Antennal club. (0) with more than 3 segments; (1) with 3 segments

Character 3.- Head. (0) flat; (1) with carina

Character 4.- Pronotal lateral sides. (0) straight or weakly serrated; (1) serrated

Character 5.- Elytral texture. (0) striated; (1) smooth.

Character 6.- Dorsal pubescence. (0) scale-shape; (1) glabrous or dishevelled filaments.

Character 7.- Metepimeron. (0) wide and without outline; (1) narrow and with border.

Character 8.- Metacoxae. (0) smooth; (1) with border.

Character 9.- Dorsal structures of the metatibiae. (0) Absent; (1) spurs.

Character 10.- Transversal carina of the metatibiae. (0) absent; (1) present

Character 11.- Hind tibiae. (0) slightly punctate and shiny; (1) strongly punctate.

Character 12.- Meso and metatibiae lateral structures. (0) present; (1) absent.

Character 13.- Genital sternite shape. (0) "Y" shaped; (1) "T" shaped.

Character 14.- Spiculum ventrale. (0) Absent; (1) present.

Character 15.- parameres/phallobase ratio. (0) greater than or equal to 1 (parameres longer than or equal to the phalobase); (1) less than 1 (parameres shorter than the phallobase).

Character 16.- Paramere ventral surface. (0) ventrally detached; (1) ventrally fused.

Character 17.- Paramere dorsal surface. (0) sclerotized in all; (1) partially sclerotized, with a narrow and membranous area in the middle with the same width throughout length (Fig. 2D); (2) partially sclerotized, with a membranous area in the middle, achieving contact in a medial point; (3) partilly sclerotized, with a membranous area in the middle, growing wider at the apex (Fig. 6D).

Character 18.- Dorsal sclerotized areas in the parameres. (0) Absent; (1) present.

Character 19.- Apices of the parameres. (0) Opened; (1) closed.

Character 20.- Apices of the parameres. (0) Rounded like two valves; (1) prolongued like two swords; (2) blunt.
Character 21.- Temones development. (0) reduced; (1) developed; (2) absent.

Character 22.- Endophallum. (0) Joined to parameres through intermediate structues (temones or median lobe); (1) joined to parameres without intermediate structures.

Character 23.- Endophallum shape. (0) Sac-shape; (1) with two caeca (Fig. 4).

Character 24.- Internal structures in the endophallum. (0) Plates; (1) absent; (2) tigillum.

Character 25.- Internal raspulae in the endofallum. (0) Inconspicous; (1) raspulae with many tricoid setae.

Character 26.- Tigillum. (0) Absent; (1) delicate constitution; (2) strong constitution.

Character 27.- Tigillum shape. (0) Without tigillum; (1) "V"'-shaped

Character 28.- Tigillum. (0) Absent; (1) convergent extreme connected with a bridge (Fig. 5A); (2) convergent extreme without bridge.

Character 29.- Tigillum length. (0) Without tigillum; (1) tigillum longer than $1 / 2$ endophallum length; (2) tigillum shorter than $1 / 2$ endophallum length. Character 30.- Insertion of the spermathecal gland. (0) In medial position; (1) in basal position

\section{Results}

\section{TAXONOMY}

DESCRIPTION OF THE GROUP OF GENERA (Fig. 1)

Antenna with ten, nine or eight segments; fifth and sixth segments may be partially fused in some species. Antennal club with three segments whose length varies from shorter than funicule to longer than stem. Clypeus shorter than frons, concave and arcuate laterally with anterior margin not strongly sinuate in the middle. Head weakly and closely punctuate and more or less pubescent. Body pubescence varies among species from abundant on body surface (including pygidium) but shorter on elytra than on pronotum and conspicuous around scutellum to being absent. Wing condition may be functional in both sexes; reduced wings in females (micropterism) and functional wings in males; and both sexes with reduced wings. Hind tibiae with lateral carina complete, with or without dorsal spurs and more or less punctate. Metepimeron narrow and with border. Tarsal claws long, slightly bent, and with a slight basal tooth.

The male genitalia correspond to that described by Coca Abia \& Martín Piera (1991). The parame- 


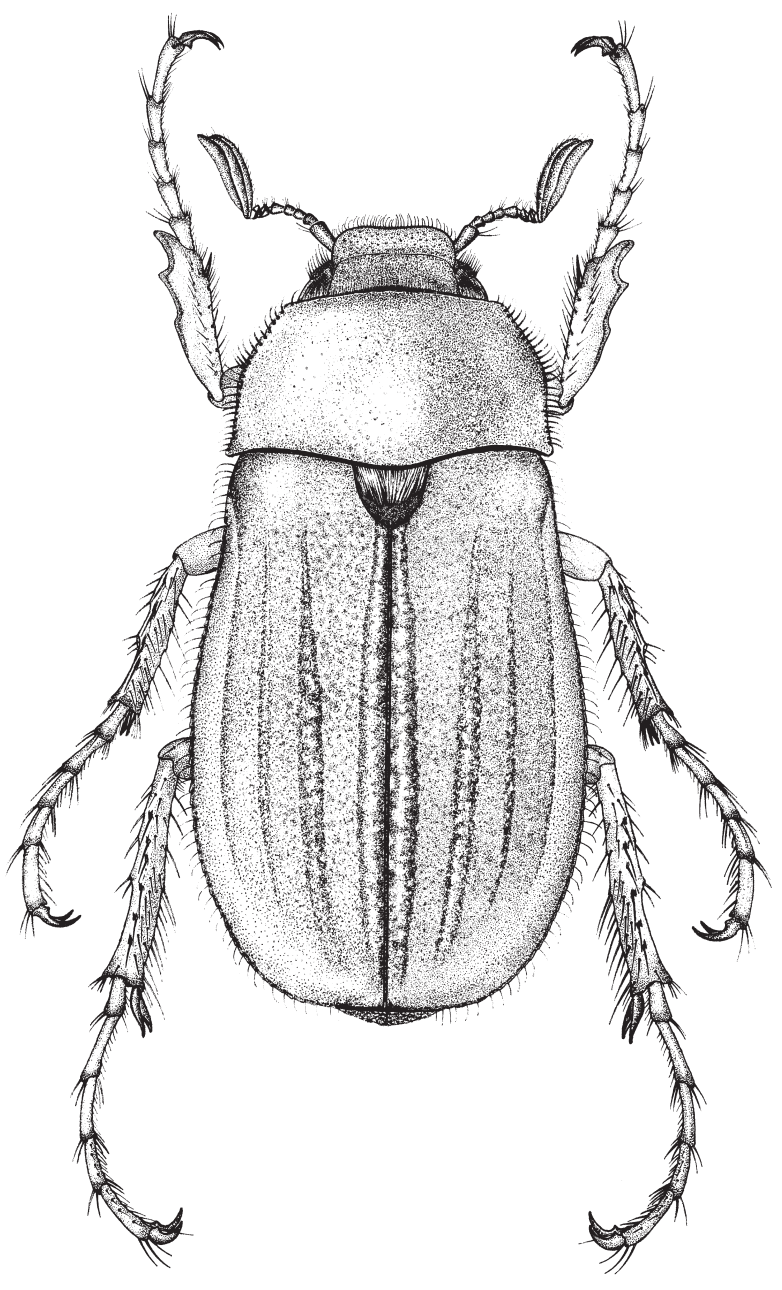

Fig. 1.- Habitus of Rhizotrogus aestivus.

Fig. 1.- Hábitus de Rhizotrogus aestivus.

res are tubular-shaped; dorsal surface with a membranous area in the middle, joined and articulated to the phallobase in medial position (Fig. 2). The endophallus is sac-shaped (Fig. 3) or with two caeca (Fig. 4); joined to the parameres apices without intermediate anchorage structures. The epithelium of the endophallus is covered with sensilla of various shapes and sizes.

The female genitalia correspond to that described by Coca-Abia and Martín Piera (1991). In ventral position the genital chamber has two plates termed sternites. In dorsal position there are two small structures named genital palpes. The median oviduct is membranous with wrinkled epithelium; bursa copulatrix with a wider proximal duct (duc-

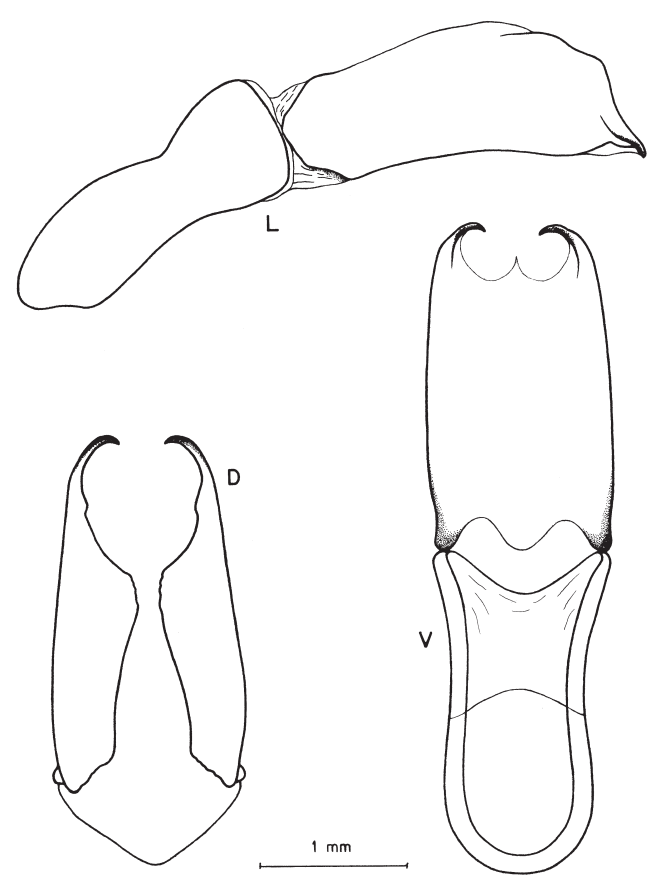

Fig. 2.- Tegmen in lateral (L), dorsal (D) and ventral (V) views of Rhizotrogus zuzartei.

Fig. 2.- Vista lateral (L), dorsal (D) y ventral (V) del tegmen de Rhizotrogus zuzartei.

tus bursae) and a distal blister (corpus bursae). Spermatheca joined on the median oviduct independently of the bursa copulatrix: Spermathecal gland meets spermatheca at different positions of its tract. The two pairs of accessory glands have unequal shape and size and one member of each pair is rounded and reduced.

\section{Genus Amadotrogus Reitter, 1902}

TYPE SPECIES: Rhizotrogus quercanus Burmeister, 1855 (designated by Baraud, 1992)

Diagnosis: Genus review by Coca-Abia \& Martín-Piera (2002). Antenna with ten segments; antennal club shorter than the stem and about the same size in both sexes. Pronotal surface glabrous and shiny, with scattered punctures; lateral margin is smooth or slightly serrate anteriorly. Elytra glabrous, shiny, and without striae. Functional wings in both sexes. Antero-dorsal portion of the parameres with dark areas more sclerotized than the remaining part of the parameres. Apices of the parameres robust and rounded, truncated in lateral view. Endophallus with two caeca projected cephalically 


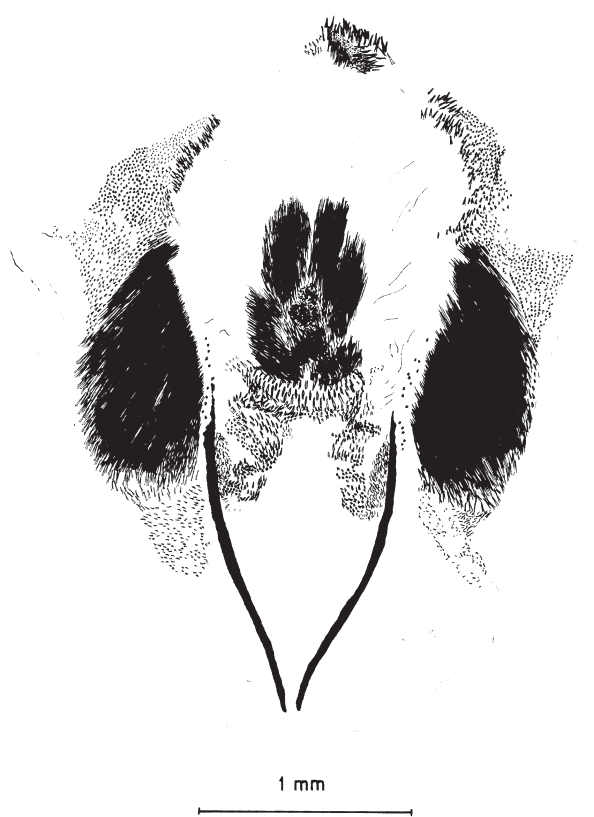

Fig. 3._- Endophallus of Rhizotrogus maculicollis.

Fig. 3.- Endofalo de Rhizotrogus maculicollis.

(Coca-Abia \& Martín-Piera, 2002), without raspulae (Coca-Abia \& Martín-Piera, 1991; Martín-Piera \& Coca-Abia, 1992), only with areas of pointed sensilla (Fig. 4). The most peculiar feature in the female genitalia is the position of the spermathecal gland. Its insertion in the spermatheca is basal, close to the median oviduct (Coca Abia \& Martín Piera, 2002).

Distribution: Amadotrogus is a WestPalaearctic Melolonthini genus, distributed across the Northern Mediterranean basin from the Iberian Peninsula to Lebanon, including Corsica and Sardinia.

Material examined: Those studied in CocaAbia \& Martín-Piera (2002).

\section{Genus Amphimallon Berthold, 1827}

= Amphimallina Reitter, 1905. (syn. nov.). Type species: Amphimallina jenrichi Reitter, 1905.

TYPE SPECIES: Scarabaeus solstitialis L., 1758.

Diagnosis: Antenna with nine segments, exceptionally 8-segmented (Montreuil, 2000), male antennal club longer than the females'. Head smooth, at most with a discontinued carina; coarsely, closely punctuate and pubescent. Pronotal surface

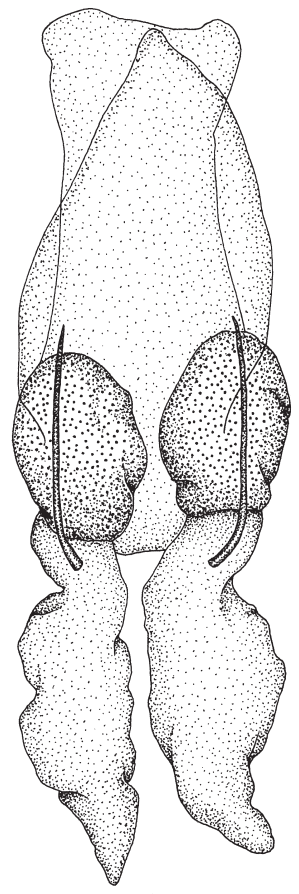

Fig. 4.— Endophallus of Amadotrogus patruelis.

Fig. 4.- Endofalo de Amadotrogus patruelis.

with small punctures, reticulated tegument. Pronotal pubescence varies among species from long, erect and dishevelled to shorter, whitish and covering surface homogenously; lateral margin varies from serrate to almost smooth. Meso- and metasternum densely populated with long hair-like setae. Some species with elytra striate, glabrous, or pubescent around scutellum. Functional wings in both sexes. Apices of the parameres sharp. Endophallus sac-shaped, with areas of pointed sensilla and soft raspulae between the tigillum which are delicate and short with the convergent extreme connected with a bridge (Fig. 5A). Female genitalia as that described by Coca Abia \& Martín Piera (1991) and Montreuil (2000).

REMARKS: The genus Amphimallina was established on the basis of the number of antennal segments (eight segments) and distal maxillary palpi-shape (Baraud, 1992). The features established to distinguish this taxa from Amphimallon have no meaning because the antennal segment can be fused, giving eight or nine antennal segments in Amphimallon (Mountreil, 2000). That character does not allow to distinguish both gene- 


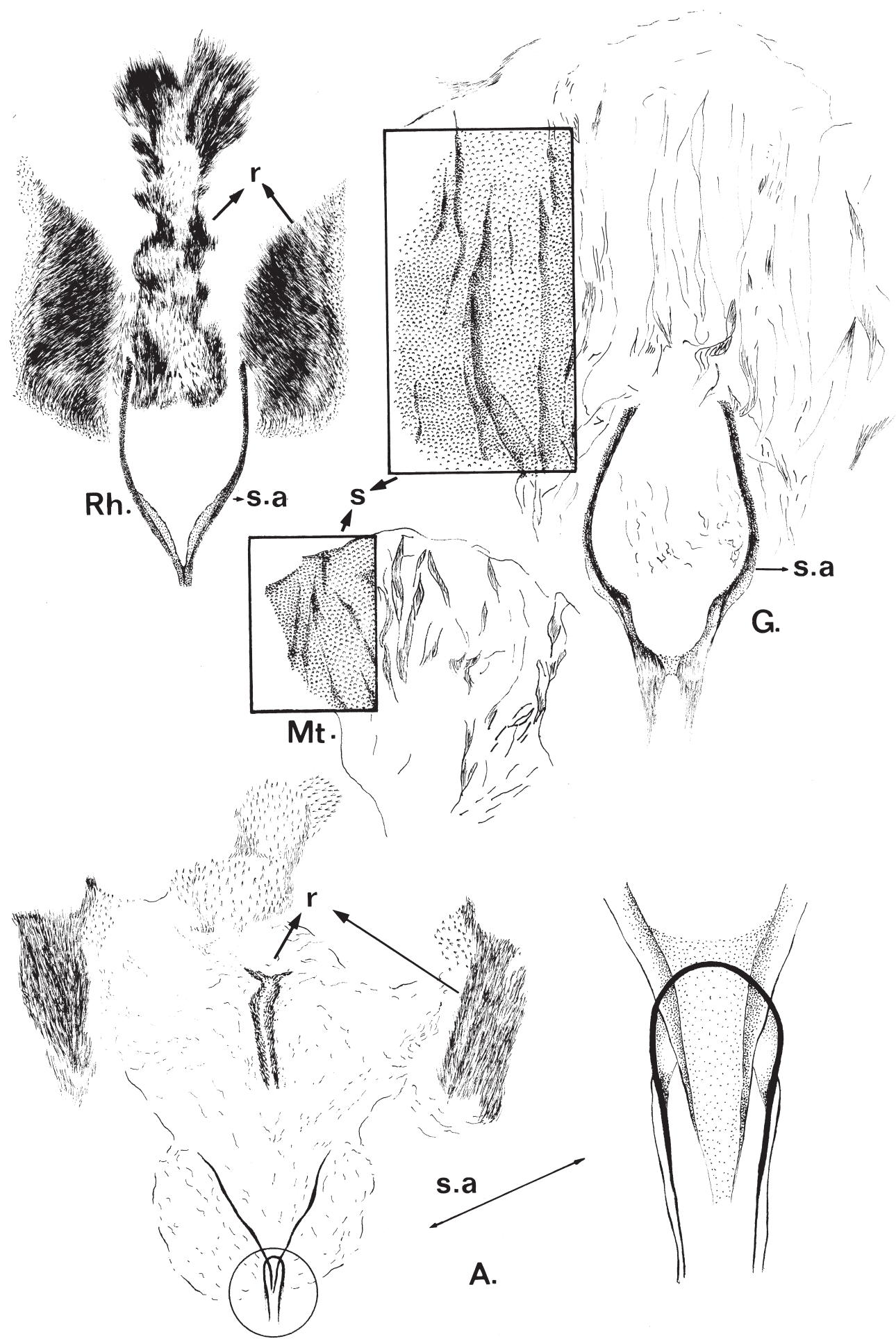

Fig. 5.-Endophallus of Rhizotrogus (Rh), Geotrogus (G), Monotropus (Mt), Amphimallon (A). r: raspullae; s: pointed sensillas; s.a.: tigillum

Fig. 5.- Endofalo de Rhizotrogus (Rh), Geotrogus (G), Monotropus (Mt), Amphimallon (A). r: ráspulas; s: sensilas puntiformes; s.a.: tigilos. 

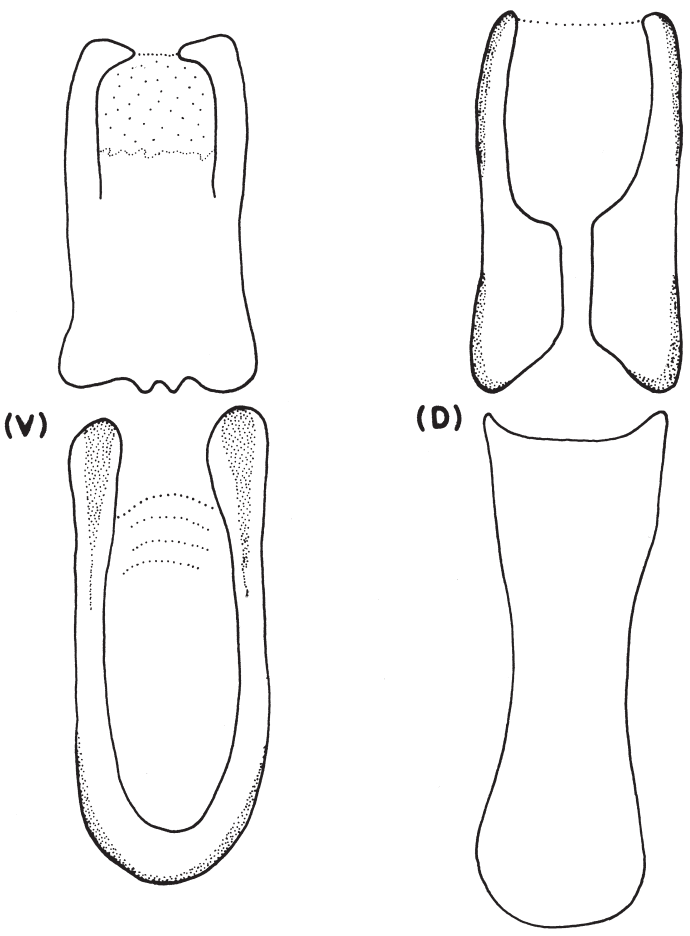

Fig. 6.- Tegmen in ventral (V) and dorsal (D) views of Geotrogus magagnosci.

Fig. 6.- Vista ventral (V) y dorsal (D) del tegmen de Geotrogus magagnosci.

ra. On the other hand, there are not enough studies of the mouth parts of those genera, which would allow to ascertain if the distal maxillary palpi-shape is an autopomorphic character of Amphimallina. External morphology and the male genitalia prove the resemblance of Amphimallon to Amphimallina. The presence of a distal bridge in the tigillum (Fig. 5A), which is a distinctive character of Amphimallon, is shared with Amphimallina. This similarity, together with the phylogenetic position of Amphimallina in the cladogram, allows to conclude that Amphimallina is synonymous with Amphimallon.

Distribution: Amphimallon is a Palaearctic Melolonthini genus, distributed across the Mediterranean basin, from the Iberian Peninsula and North Africa to Romania, Bulgaria, Greece, Caucases and Russia.

Material eXamined: Those studied in CocaAbia (1995).

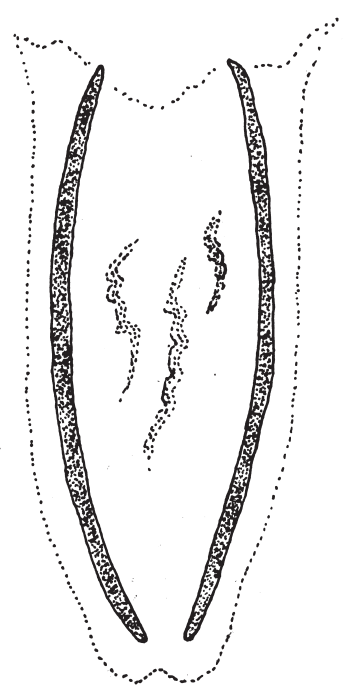

Fig. 7.- Endophallus of Geotrogus magagnosci.

Fig. 7.- Endofalo de Geotrogus magagnosci.

\section{Genus Geotrogus Guérin-Méneville, 1842}

= Pseudoapterogyna Escalera, 1914. (syn. nov.). Type species Pseudoapterogyna tusculus (Buquet, 1840).

TYPE SPECIES: Geotrogus magagnosci GuérinMéneville, 1842

Diagnosis: Antenna with ten segments; antennal club shorter than the stem and about the same size in both sexes. Head smooth; scattered punctures. Pronotal surface with small punctures, reticulated tegument. Pronotal surface mainly glabrous or, at most, anterior and posterior edges pubescent; lateral margin smooth. Elytra smooth. Meso- and metatibiae smooth and shiny with scattered punctures. Males with functional wings, females always micropteres and in some species males are micropteres. Dorsal surface of the parameres has a membranous area towards the middle growing wider at the apex (Fig. 6D). Endophallus sac-shaped, without raspulae, with areas of pointed sensilla and strong tigillum (Figs. 5G, 7). Female genitalia as described by Coca Abia \& Martín Piera (1991).

RemARKs: Geotrogus and Pseudoapteregyna have been considered to be independent taxa. The features established to distinguish one from the other are the wing condition (Baraud, 1985), elytrashape and coxa-size. The loss of wings is an adaptation to desert environment. It can be seen in other species which inhabit the desert, such as the subgenus Eugastra found in Arizona. The loss of wings has led to some morphological changes of elytra 
and coxae. These characters are the consequence of an adaptation to the environment and must not be considered as good diagnostic characters. On the other hand, the external morphology of other, nonadaptive, characters and the male genitalia prove the resemblance between both taxa. Consequently, Pseudoapterogyna is synonymous with Geotrogus.

DistRIBUTION: North Africa, Corsica and Sardinia.

MATERIAL EXAMINED: Those studied in Coca-Abia (1995). Geotrogus magagnosci (types 10", 1 O) (Argel); Pseudoaptergyna tusculus (Types 2000') (Constantine, Algeria).

\section{Genus Monotropus Erichson, 1847}

TYPE SPECIES: Monotropus nordmanni Blanchard, 1850.

DiAGNOSIS: Antenna with eight segments; antennal club longer than the stem and male antennal club longer than the females'. Pronotal surface glabrous or pubescent; serrated lateral margin. Elytra weakly striated. Functional wings in both sexes. Apices of the parameres robust. Endophallus sacshaped, without raspulae, with areas of pointed sensilla and without tigillum (Fig. 5Mt). Phallobase ventrally sclerotized and closed and strongly sinuate in the middle. Female genitalia as that described by Coca Abia \& Martín Piera (1991).

REMARKS: The phylogenetic analysis below does not allow to confirm that those transferred from Rhizotrogus by Coca-Abia \& Martín-Piera (1998) are established as a species belonging to Monotropus. Neither, can these species be assigned to other genera, so they remain as incerte sedis.

Distribution: Endemic to West Europe.

MATERIAL EXAMINED: Those studied in CocaAbia (1995) and Rhizotrogus transferred to Monotropus (Coca-Abia \& Martín-Piera, 1998).

\section{Genus Rhizotrogus Berthold, 1827.}

TYPE SPECIES: Melolontha aestiva Olivier, 1789 (Fig. 1).

Diagnosis: Antenna with ten segments; male antennal club longer than females' and as long as the stem. Head smooth, at most with a discontinued carina; coarsely, closely punctuate and pubescent. Pronotal surface with scattered or closely-spaced punctures. Pronotal pubescence varies among the species, from long, erect and dishevelled to shorter; serrate lateral margin. Elytra glabrous or pubescent around scutellum. Meta- and mesotibiae with spurs in dorsal position. Functional wings in both sexes. Strong parameres. Endophallus sac-shaped, with areas of pointed sensilla and thick raspulae between the tigillum, which are strong (Figs. 3 and 5Rh). Female genitalia as that described by Coca Abia \& Martín Piera (1991).

DistRIBUTION: Mediterranean basin, Northern Europe.

Material eXamined: Those studied in CocaAbia (1995) and Coca-Abia \& Martín-Piera (1998).

\section{Genus Firminus (new genus)}

TYPE SPECIES: Rhizotrogus punicus Burmeister, 1855.

DiAGNOSIS: Antenna with ten segments; antennal club shorter than the stem and about the same size in both sexes. Head smooth, coarsely, closely punctuate and more or less pubescent. Pronotal surface with scattered or closely-spaced punctures. Pronotal pubescence varies among species, from long, erect and dishevelled, to shorter or glabrous; smooth lateral margin. Elytra glabrous or pubescent. Meta- and mesotibiae without spurs in dorsal position, shiny with scattered punctures. Functional wings in both sexes. Apices of the parameres blunt. Parameres shorter than the phallobase and laterally sinuate (Fig. 8). Endophallus sac-shaped, with areas of pointed sensilla and without raspulae, strong and large tigillum (Fig. 9), almost as long as the sac. Female genitalia as that described by Coca-Abia \& Martín Piera (1991).

ETYMology: The genus name is dedicated to Dr. Fermín Martín-Piera, professor and fellow of the author. His enthusiastic participation in Melolonthinae beetle research inspired the life work of the author and a love for these insects.

SPECIES INCluded: Firminus alsasuanus (Reitter, 1902), Firminus baudii (Brenske, 1886), Firminus beilleri (Reiche, 1862a), Firminus ciliatus (Reiche, 1862b), Firminus fossulatus (Mulsant \& Rey, 1859), Firminus lautiusculus (Schaufuss, 1864), Firminus procerus (Baudi, 1870), Firminus punicus (Burmeister, 1855) y Firminus putoni (Reitter, 1902).

DistRIBUTION: Mediterranean area: Spain, Italy, Corsica, Sardinia, Sicily, Yugoslavia, Albania, Greece, Austria.

REMARKS: The species Rhizotrogus punicus (Burmeister, 1855) is considered type species of the genus Firminus. A male of this species, placed in Martin-Luther-Universitat Halle-Wittenberg (Saale), 

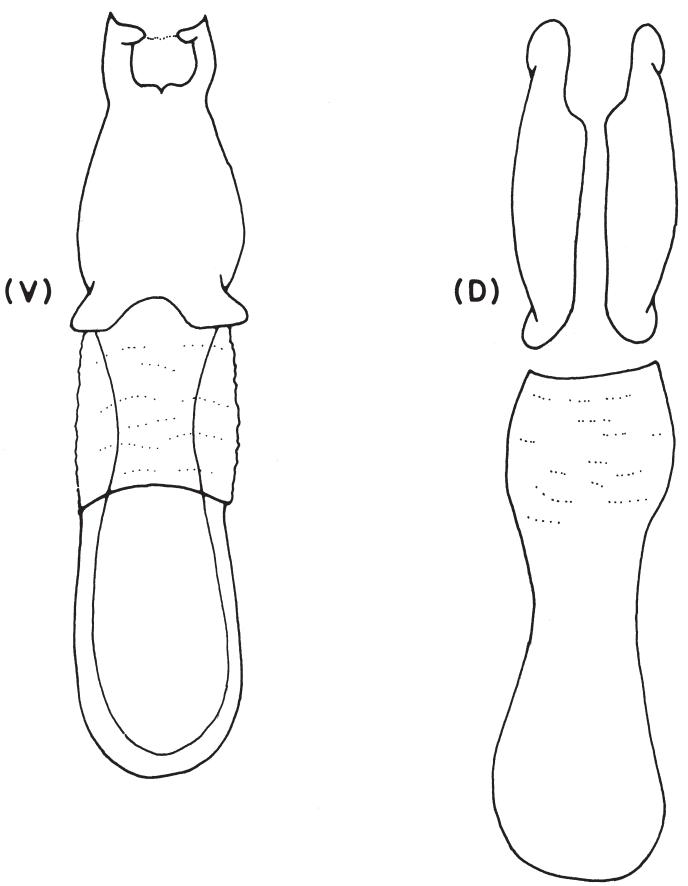

Fig. 8. - Tegmen of Firminus punicus. Dorsal view (D) and ventral view $(\mathrm{V})$.

Fig. 8.- Vista dorsal (D) y ventral (V) del tegmen de Firminus punicus.

is designated as the Holotype, labelled with a red and printed label: Holotype, m Firminus punicus (Burmeister, 1855) Coca-Abia, 2003.

Material eXAmined: Those studied in CocaAbia (1995) and Coca-Abia \& Martín-Piera (1998).

\section{Phylogenetic analysis}

The analysis using equal weights yielded five equally parsimonious cladograms, each with 44 steps, consistency index (CI) of 0.864 , and retention index (RI) of 0.910 . Two rounds of successive weighting (base weight 1000) yielded five trees of a length of 360 steps, $\mathrm{CI}=0.944$ and $\mathrm{RI}=0.962$.

The phylogenetic hypothesis (Fig. 10) suggests that the group of genera of Amadotrogus, Amphimallon, Firminus, Geotrogus, Monotropus and Rhizotrogus is a monophyletic group, which is strongly supported (bootstrap 98\%) by synapomorphic characters (characters 14, 16, 17, 19, 20, 21,22 ), such as: a) spiculum ventrale present; b) ventral surface of the parameres fused; c) dorsal surface of the parameres with a membranous area;

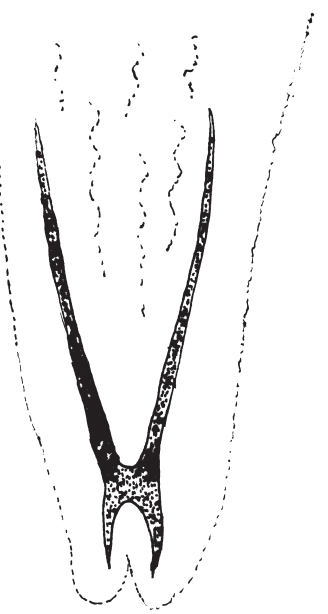

Fig. 9.- Endophallus of Firminus punicus.

Fig. 9.- Endofalo de Firminus punicus.

d) apices of the parameres closed; e) blunt apices of the parameres; f) absent temones; g) endophallum joined to the parameres without intermediate structures (temones or median lobe).

The genera Amphimallon and Rhizotrogus are strongly supported, with a bootstrap of $93 \%$ and $78 \%$ respectively. Also, Amphimallina is related to Amphimallon, seen to be constituting the same taxon with considerable support (bootstrap 69\%).

Geotrogus and Pseudoapterogyna fall in a monophyletic group, that is well supported (bootstrap of $68 \%$ ) by the synapomorphy of the hind tibiae, weakly punctate and shiny tegument (character 11). Also, Geotrogus genei (Blanchard, 1850), which was transferred from Rhizotrogus to Geotrogus (CocaAbia \& Martín-Piera, 1998), belongs to this clade. The remaining species transferred from Rhizotrogus to Geotrogus (Coca Abia \& Martin-Piera, 1998) make up a monophyletic group, with support of $51 \%$ bootstrap. This clade is supported by the synapomorphy of parameres shorter than the phallobase (character 15).

The genus Amadotrogus shows significant support in its branch (bootstrap 97\%) that confirms the existence of autopomorphic characters established by Coca-Abia \& Martín-Piera (2002).

Species formerly transferred from Rhizotrogus to Monotropus (Coca-Abia \& Martín-Piera, 1998) lack synapomorphies which would justify their inclusion in Monotropus. Neither do these species constitute a monophyletic group but rather make up a basal polytomy. 


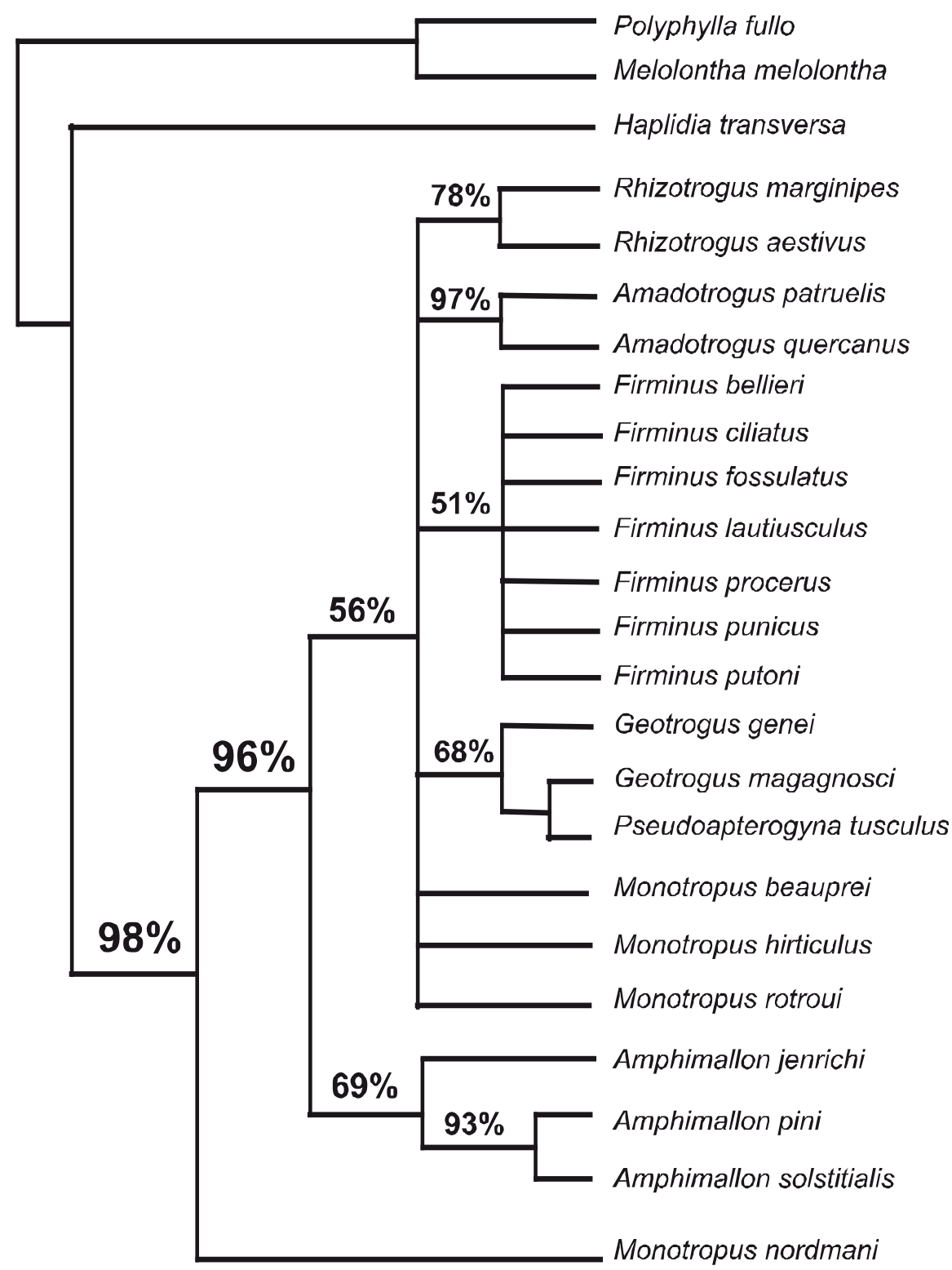

Fig. 10.- Bootstrap 50\% Majority-rule consensus tree. The numbers on the branches indicate the bootstrap support.

Fig. 10.- Árbol consenso con Bootstrap 50\% Majority-rule. Los porcentajes sobre las ramas indican el soporte Bootstrap.

\section{Discussion and conclussions}

The West Mediterranean genera Amadotrogus, Amphimallon, Firminus, Geotrogus, Monotropus and Rhizotrogus constitute a monophyletic group (Fig. 10), very well-supported (bootstrap 98\%). Character sharing by all these genera highlight the overall similarity between them (Coca-Abia \&
Martín-Piera, 1998) and the plesyomorphic significance of these characteres for the clade.

Geotrogus is well-supported with a bootstrap of 68\% (Fig. 10) and supported by autapomorphic characters (11) which distinguish it from its allied genera. These distinctive characters are also shared by Geotrogus genei, which was correctly transferred from Rhizotrogus to Geotrogus (Coca-Abia \& 
Martín-Piera, 1998), and by Pseudoapterogyna tusculus type species of the genus Pseudoapterogyna. The phylogenetic position of this taxa in the cladogram, together with morphological and genitalic features currently used as taxonomic characters, allow herein to establish Pseudoapterogyna as synonymous with Geotrogus.

Whereas the remaining species transferred from Rhizotrogus to Geotrogus constitute a clade, which herein is considered a new genus Firminus, supported by synapomorphic character in the edeagus (15).

Amadotrogus is strongly supported and a wellestablished natural group, supporting the conclusions of Coca-Abia \& Martín-Piera (2002).

Amphimallina is related to Amphimallon, that allows to establish Amphimallina as synonymous taxon with Amphimallon.

The species formerly transferred from Rhizotrogus to Monotropus (Coca-Abia \& MartínPiera, 1998) do not constitute a monophyletic group, they can not be considered belonging to Monotropus remaining as incerta sedis.

Finally, the analysis allow to consider the West Mediterranean genera Amadotrogus, Amphimallon, Firminus, Geotrogus, Monotropus and Rhizotrogus a monophyletic group but does not shed light on their phylogenetic relationships. This basal polytomy could be considered from two points of view, either from that of "soft" polytomy or "hard" polytomy (Coddington \& Scharft, 1996). Seen from the first point, the lack of data in the external morphology and genitalia does not lead to a solution; some other methodology, such as molecular analyses would be necessary. From the second point, it could be that basal radiation led to the diversification of the Rhizotrogini in the West Mediterranean.

\section{ACKNOWLEDGMENTS}

I wish to thank the colleagues and institutions who lent the necessary material to write this paper: Dr. Claude Girard (Museum d'Histoire Naturelle of Paris); Dr. Roberto Poggi (Museo Civico "Giacomo Doria" of Genova); Dr. Alberto Sendra (Fundación "Torres Sala" of Valencia); Dr. Karla Schneider (Institut für Zoologie der Martin-LutherUniversität Halle) and Dr. Hella Wendt (Museum für Naturkunde of Berlin).

The individual people who lent me the material from their collections: Dr. Antonio Andujar, Dr. Jose Miguel Avila and Dr. Jose Luis Lencina.

Dr. Miguel Angel Alonso Zarazaga (Museo Nacional de Ciencias Naturales of Madrid) provided taxonomic and nomenclatural advice.

Emilio Soteras, José Arroyo and Carmen Galván (Museo Nacional de Ciencias Naturales of Madrid) produced the illustrations.
Dr. Alfonso Navas Sánchez and Dr. Jorge Miguel Lobo (Museo Nacional de Ciencias Naturales of Madrid) provided the facilities for carrying out the research.

\section{References}

Alvarado, M., Serrano, A., Duran, J. M. \& DE la RosA, J. M., 1996. Problemática de los gusanos blancos (Coleoptera, Scarabaeidae) en el olivar de la provincia de Sevilla. Boletín de Sanidad Vegetal Plagas, 22(2): 319-328.

BARAUD, J., 1985. Coléoptères Scarabaeoidea: Faune du Nord de l'Afrique du Maroc au Sinaï. Lechevarier. Paris. 651 pp.

BARAUD, J., 1992. Coléoptères Scarabaeoidea d'Europe. In: Faune de France, vol. 78. Publication de la Federation française des Sociétés des Sciences Naturelles et Société Linnéenne de Lyon. Lyon. 856 pp.

Baudi a Selve, F., 1870. Coleopterorum messis in insula Cypro et Asia monore ab Eugenio Truqui congregatae recensitio: de Europaeis notis quibusdam additis. Berliner Entomologische Zeitschrift, 14: 49-90.

BERTHOLD, A. A., 1827. Latreille's natürliche Familien des Thierreichs mit anmerkungen und Zusätzen. Industr. Compt. Weimar. $8+602$ pp.

BlanChard, E., 1850. Catalogue de la collection entomologique. Casse des Insectes. Ordre des Coléoptères. Catalogue de la Collection Entomologique. Classe des Insectes. Ordre des Coléoptères, 1: 144-148.

Brenske, E. 1886. Ueber Melolonthiden. Deutsche Entomologische Zeitschrift, 30(1): 1995-207.

BuQuet, M. L. 1840. Note sur sept espèces algériennes du genre Rhizotrogus. Reuve Zoologique, 1840: 171172 .

Burmeister, H. C. C., 1855. Handbuch der Entomologie, vol. 4(2). Theod. Chr. Fr. Enslin. Berlin. $10+570$ pp.

CocA-ABIA, M., 1995. Taxonomía, Filogenia y Biogeografia del género Rhizotrogus Berthold, 1827 en el Mediterráneo Occidental. Ph. D. Dissertation. Universidad Complutense. Madrid. 351 pp.

CocA-ABia, M. \& Martín-Piera, F., 1991. Anatomy and morphology of the genitalia in the subtribe Rhizotrogina (Col. Melolonthidae, Melolonthini): taxonomic implications. In: M. Zunino, X. Bellés \& M. Blas (eds). Advances in Coleopterology. European Association of Coleopterology. Barcelona: 61-78.

Coca-Abia, M. \& Martín-Piera, F., 1998. Revisión taxonómica del genéro Rhizotrogus Berthold, 1827 (Coleoptera, Scarabaeidae, Melolonthinae). Elytron Monographs, 2: 1-116.

COCA-ABiA, M. \& Martín-Piera, F., 2002. Revision of the genus Amadotrogus Reitter, 1902 (stat. nov) (Coleoptera: Scarabaeidae: Melolonthinae). Annales de la Société Entomologique de France, 38(4): 351-362.

Coddington, J. \& ScharfF, N., 1996. Problems with "soft" polytomies. Cladistics, 12(2): 139-145. 
ERICHSON, W. F., 1847. Naturgeschichte der Insecten Deutschlands. Coleoptera. Scarabaeides pleurosticti. Melolonthidae. Nicolaische Buchhandlung. Berlin. pp. 656-661.

EscalerA, M. M. DE LA, 1914. Los Coleopteros de Marruecos. Trabajos del Museo Nacional de Ciencias Naturales. Serie Zoológica, 11: 169-175.

Felsenstein, J., 1985. Confidence limits on phylogenies: an approach using the bootstrap. Evolution, 38: $16-24$.

FITCH, W. H., 1971. Towards defining the course of evolution: Minimal change for a specific tree topology. Systematic Zoology, 20: 406-416.

GuÉRIN-MÉNEVILLE, F. E., 1842. Sur un groupe a séparer du genre Rhizotrogus Latr. Et description du $R$. Mayagnoscii. Revue de Zoologie, 1842: 6-8.

Krell, F. T., 1996a. Die Kopulationsorgane des Maikafers Melolontha melolontha (Insecta: Coleoptera: Scarabaeidae). - Ein beitrag zur vergleichenden und funktionellen Anatomie der ektodermalen Genitalien der Coleoptera. Stuttgarter Beiträge zur Naturkunde Serie A, 537(31): 1-101.

Krell, F. T., 1996b. Corresponding genital muscles in male and female Melolontha melolontha (Coleoptera: Scarabaeidae) as indicators of morphological correspondence in male and female genital sclerites. Proceedings XX International Congress of Entomology, Firence, Italy: 126.

LinNÉ, C., 1758. Systema Naturae. Ed. 10. Holmiae. $823 \mathrm{pp}$.

MadDison, W. P. \& MAdDISON, D. R., 1992. MacClade: Interactive analysis of phylogeny and character evolution. Version 3.07. Massachusetts. 199 pp.

Martín-Piera F. \& CoCA-ABiA, M., 1992. Revisión taxonómica del género Rhizotrogus Berthold, 1827: El grupo de $R$. cicatricosus Mulsant, 1842 (Coleoptera: Melolonthidae). Elytron, 6: 199-219.

Montreuil, O., 2000. Cladistic systematics of the genus Amphimallon (Coleoptera: Scarabaeidae: Melolonthinae). European Journal of Entomology, 97: 253-270.
Mulsant, E. \& Rey, C., 1859. Description de quelques Coléoptères nouveaux. Annales de la Société Agricole de Lyon, 3(3): 222-240.

NiXon, K. C. \& CARPENTER, J. M., 1993. On outgroups. Cladistics, 9: 413-426.

Olivier, A. G., 1789. Entomologie ou Histoire Naturelle des Insectes avec leurs caracteres génériques et specifiques, leur description, leur synonymie et leur figure enluminée. Coléoptères. Vol. 1. Baudomin. Paris. 497 pp.

Paulian, R. \& Baraud, J., 1982. Faune des Coléoptères de France. II, Lucanoidea et Scarabaeoidea. Lechevalier. Paris. 477 pp.

ReICHE, M. L., 1862a. Espèces nouvelles de Coléoptères. Découvertes en Corse par M. El. Bellier de la Chavignerie en 1961. Annales de la Société Entomologique de France, (4), 2: 293-300.

Reiche, M. L., 1862b. Espèces nouvelles de Coléoptèresappartenant a la faune CircaMéditerranéenne. Annales de la Société Entomologique de France, (4), 2 : 539-546.

ReitTer, E., 1902. Bestimmungs-Tabelle der Melolonthidae aus der Europaischen Fauna und den angrenzenden Ländern. L. Pachydemini, Sericini und Melolonthini. Verhandlungen des Naturforschenden Vereins in Brünn, [1901], 40: 93-303.

ReitTer, E., 1905. Neun neue Coleopteren aus der palaearktischen Fauna. Wiener Entomologische Zeitung, 24: 201-206.

SCHAufuss, L. W., 1864. Beschreibung einiger nev entdechter káfer. Verhandlungen des ZoologischBotanischen Gesellschaft in Wien, 14: 673-676.

SwOFford, D. L., 1993. PAUP: Phylogenetic Analysis Using Parsimony, Version 3.1. Illinois. 253 pp. 